\begin{tabular}{|c|c|c|c|}
\hline \multicolumn{4}{|c|}{ 横須賀共済病院内科 } \\
\hline 木嶋 & 祥麿○ & 小沢＼cjkstart潔 & 桜井俊一朗 \\
\hline 仲山 & 勲 & 東海林隆男 & 笹岡 拓雄 \\
\hline
\end{tabular}

\title{
A CHRONIC UREMIC PATIENT WITH COAGULOPATHY INDUCED BY VITAMIN K DEFICIENCY
}

\author{
Yoshimaro Kijima, MD, Kiyoshi Ozawa, MD, Shun-ichiro SakuraI, MD \\ Isao NAKAYAMA, MD, Takao SHŌjI, MD, and Takuo SASAOKA, MD \\ Department of Internal Medicine, Yokosuka Kyosai Hospital, Yokosuka
}

\begin{abstract}
概要 腎障害が進行すると血液凝固の異常が生じ，四肢に出血斑をみることがある，しかし， 通常, 致命的な出血素因になることはない，一方，尿毒症になると消化器症状のため食事揕取 量が著しく減少するが，それだけでビタミンK欠之性出血を併発する例はあまり知られていな

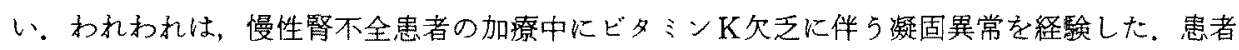
は71才で，10年来高血生とたんぱく尿のため近医にて治療を受けていた，最近腎機能が悪化し てきており, 頑固な悪心・呕吐, 食欲不振がつづいていた。 入院時, 顔面浮腫, アンモニア臭, 口唇の亀裂からの出血がみられ，検査の結果尿毒症と診断した，腹膜透析により著しく改善し たが，内シャント手術後抗生物質を投与し6日後に黒色便，その翌日は術部からの再出血をみ た。プロトロンビン時間・部分トロボプラスチン時間は延長しており，検査上DICや高度の肝障 害は否定され, phytonadione投与にて改善したことから，ビタミンK久乏性出血症と診断した。 高令で腎障害のある患者では食事不足に陷りやすく，また抗生物質の投与む加わると比較的容 易にビタミンK欠之状態に陷つてしまらと考光られる。このような例の報告はいまだ少なく， 腎不全患者を診るうえで充分留意されるべき合併症の一つであるといえる。
\end{abstract}

\section{鍺 言}

腎機能障害が高度に進行すると，血液学的には 負血ばかりではなく，血小板機能や凝固能の異常 が生じて凝固・線溶系の機能異常が抢こることは すでによく知られている1)。そのため末期腎不全 患者ではしばしば皮膚の出血斑や鼻出血などの出 血傾向がみられ，高血圧・動脈硬化症・消化性漬 瘍があれば重要藏器での致命的な出血につながる 危険性もある。しかし，多くの患者に执いて蛅 血時間・全血凝固時間はほ注正常であり，シャン 卜手術や透析療法に際して支障となることはな い.

〔昭和 57 年 3 月 8 日受稿〕
最近われわれは，消化器症状のつついていた尿 毒症患者の加療中に突然の出血症状とともにプロ トロンビン時間・部分トロンボプラスチン時間の 著明な延長がみられ，phytonadioneの投与後影著 な欧善をみた例を経験したのでその経過を報告 し，あわせて病因について若干の考察を加えた。

\section{症例}

患者：71才，主婦.

主訴：頑固な悪心・呕吐，食欲不振，高度の 腎機能低下.

家族歴：4人の子供は軽度の高血圧.

既往歴：30年前に高血王の指摘をうけた。 10 年前に腎疾慗，心疾患といわれ，近医にて加療を つつけていたが，一昨年より血清尿素窒素(BUN) 
が上昇してきていた。

現病歴：昭和 56 年 7 月初旬，全身倦意感が出 現した。中旬には頑固な悪心・呕吐が出現して食 欲は著しく減少し，労作時呼吸困難も出てきた。

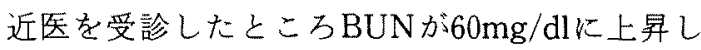
ているといわれ，7月20日当内科に転院してきた。 初燮時浮腫はなかつたが，呕吐反射がつよく䀫結

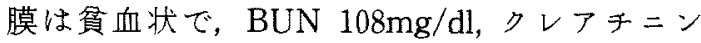
$11.9 \mathrm{mg} / \mathrm{dl}$ で, 血清カリウムは $5.9 \mathrm{mEq} / l$ と高值で あつた，食事摂取が不能となつたため 7 月25日に 緊急入院した。

入院時現症：悪心はやや落ちついたが，全身 倦点感・両上肢のしびれ感はつづいていた。体格・ 栄養之も中等で，意識は清明。体幹・四肢に浮腫 はなかつたが，顔面は浮董状であつた。唇は乾 燥して亀裂があり，出血塊が付着していた。両上 肢には多数の斑状出血斑が認められた。卧位で頚 静脈が怒張しており，血王は $190 / 80 \mathrm{mmHg}$ ，脈拍 は71/分で不整なし、聴診では駆出性心雑音が聴取 され，呼吸音では両下肺野に小水泡性ラ音が聴取 された。腹部平坦で腹壁静脈の怒張はなく，触診 では肝・腎・脾はいずれも触知せず，腹水も陰性 であつた。神経学的には異常はみられなかつた。

入院時検査成績(表 1)：末梢血では高度の正 球性正色素性貧血があり，白血球は好中球増加
伴つて $16800 / \mathrm{mm}^{3}$ と増加していた，血液生化学で は，血清総たんぱくは正常下限で $\alpha_{2}$ グロブリンの 増加がみられた。GOT, GPTは正常で，コリンエ ステラーゼは低值であつた，血清電解質ではカり ウムは軽度低く，カルシウムは著明な低值かつ無 機リンは著明な高値であり, BUNは $113 \mathrm{mg} / \mathrm{dl}$, ク レアチニンは $12.9 \mathrm{mg} / \mathrm{dl}$ とさらに上界していた。 血液凝固系檢査では出血時間・全血凝固時間はと もに正常で，活性化部分トロンボプラスチン時間 (APTT)・カオリン添加部分トロンボプラスチン 時間 (KPTT) はいずれも正常域内にあつたもの の,プロトロンビン時間 (PT) は16.2秒と延長し ていた(正常11〜13秒). また血中フィブリノーゲ ンは $660 \mathrm{mg} / \mathrm{dl}$ と高值であつた。動脈血ガスは $\mathrm{pH}$ 7.227, $\mathrm{PO}_{2} 90.1 \mathrm{mmHg}, \mathrm{Pco}_{2} 22.8 \mathrm{mmHg}$, base excess $-16.7 \mathrm{mEq} / l,\left[\mathrm{HCO}_{3}^{-}\right] 9.1 \mathrm{mM} /$ lであり， 高度の代謝性アシドーシスを呈していた。 anion gapは $26.1 \mathrm{mEq} / l$ と高值であつたが，血糖は正常 上限，尿ケトン体は陰性であつたことより，尿毒 症性アシドーシスと考えた。胸部X線像では両下 肺野のらつ血像と両側胸腔内の胸水貯留がみら れ，心胸比は70\%で心陰影は著しく拉大していた。 また时静脈王は $110 \mathrm{mmH}_{2} \mathrm{O}$ と上昇しており，5つ 血性心不全と診断した。

入院後の経過(図 1)：入院後ただちにジギタ

表 1. 入院時一般娭查結果

\begin{tabular}{|c|c|c|c|c|}
\hline (1)末束梢血啵像 & 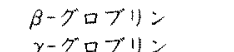 & $8.2 \%$ & 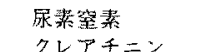 & $113 \mathrm{mg} / \mathrm{dl}$ \\
\hline $6.2 \mathrm{~g} / \mathrm{dl}$ & LDH & $390 \mathrm{IU} / \mathrm{l}$ & 空腹眭血糖 & $122 \mathrm{mg} / \mathrm{dl}$ \\
\hline $17.7 \%$ & $\gamma-G T P$ & $10 \mathrm{IU} / \mathrm{l}$ & (3)尿榆查 & \\
\hline $87.9 \mu \mathrm{m}^{3}$ & GOT & $18 \mathrm{IU} / 1$ & たんばく & $(\mathrm{tt})$ \\
\hline $30.7 \mu \mu \mathrm{g}$ & GPT & $1 \mathrm{IU} / l$ & 糖 ： & $(-)$ \\
\hline $16800 / \mathrm{mm}^{3}$ & Alk-P-ase & $243 \mathrm{IU} / \mathrm{l}$ & ウロビリノーゲン & $( \pm)$ \\
\hline 胃娟球 & 総ビリルビン & $0.4 \mathrm{mg} / \mathrm{dl}$ & ケトン体 & $(-)$ \\
\hline 好中球，桴状球 $13 \%$ & TTT & 0.4 単值 & 沈濋：赤助球 & $8-9 / \mathrm{HPF}$ \\
\hline 分葉球 $70 \%$ & ZTT & 2.9 単位 & 白血球 & $3 / \mathrm{HPF}$ \\
\hline 好酸球 & コリン・エステラーゼ & $4301 \mathrm{IU} / l$ & 上皮細胞 & $30 / \mathrm{HPF}$ \\
\hline 好塩基球 & アミラーゼ & $456 \mathrm{IU} / l$ & (4)模便 & \\
\hline 俸 球 & 総コレステロール & $159 \mathrm{mg} / \mathrm{dl}$ & 潜 血 & $( \pm)$ \\
\hline リン八球 & 中性脂肪 & $100 \mathrm{mg} / \mathrm{dl}$ & 奇生虫卵 & $(-)$ \\
\hline $23.3 \times 10^{4} / \mathrm{mm}^{3}$ & リン脂筫 & $170 \mathrm{mg} / \mathrm{dl}$ & (5)血液凝固乐模査 & \\
\hline 䄳赤血球数 & $\mathrm{Na}$ & $136 \mathrm{mEq} / \mathrm{l}$ & 出血時間 & 2分30杪 \\
\hline (2)血液生化学 & $\mathrm{K}$ & $3.1 \mathrm{mEq} / \mathrm{l}$ & 全血凝固時間 & 10 分 30 秒 \\
\hline 血清たんぱく & $\mathrm{Cl}$ & $101 \mathrm{mEq} / \mathrm{l}$ & PT & 16.2 秒 \\
\hline $\mathrm{A} / \mathrm{G}$ & $\mathrm{Mg}$ & $1.1 \mathrm{mEq} / \mathrm{l}$ & APTT & 25.8 秒 \\
\hline アルブミン & $\mathrm{Ca}$ & $1.9 \mathrm{mEq} / \mathrm{l}$ & KPTT & 80.0 秒 \\
\hline 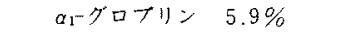 & 無機リン & $12.0 \mathrm{mg} / \mathrm{d} !$ & フィブリ/ーダン & $660 \mathrm{mg} / \mathrm{dl}$ \\
\hline$a_{2}-$ ゲロブリン $17.2 \%$ & 尿酸 & $10 \mathrm{mg} / \mathrm{dl}$ & & \\
\hline
\end{tabular}




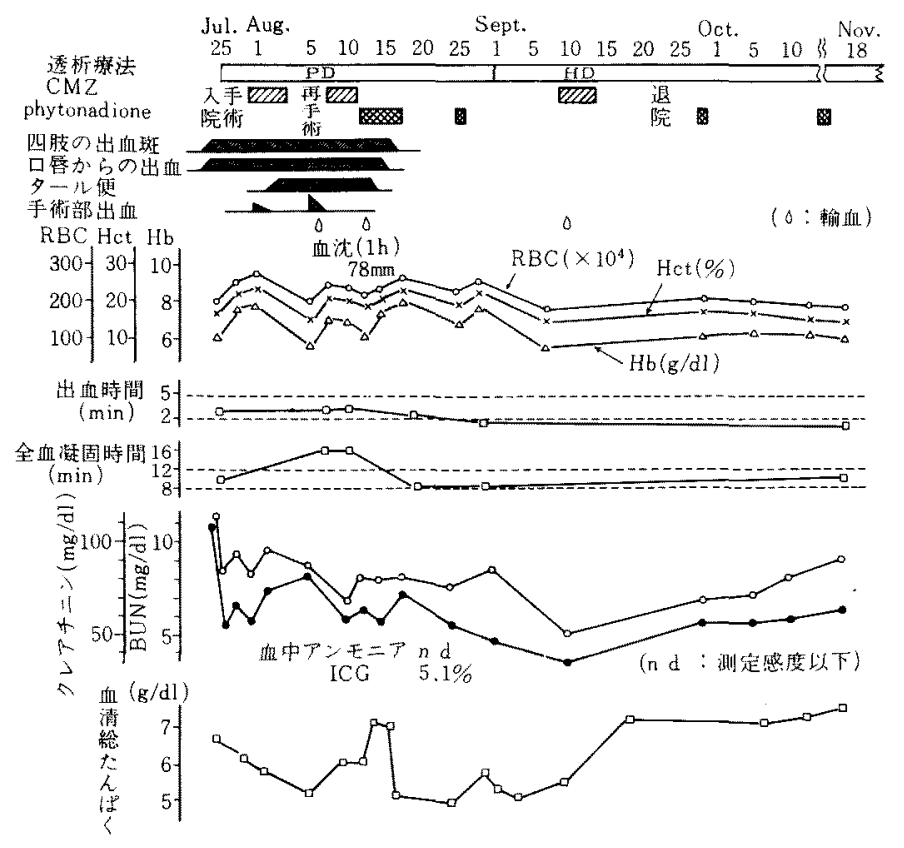

図1。入院経過

リス療法と腹膜透析 (PD) を開始したところ，3 日目には食事が摄れるようになり，第 5 病日に左 前腕内シャントをつくつた，術後感染予防のため 4 日間CMZ $2 \mathrm{~g}(50 \mathrm{mg} / \mathrm{kg})$ の静注を行なつた. 手術の 3 日後, 释合部から少量の出血をみたが， 开迫にて止血できた. 翌日口唇の出血がやや増し， 黒色便子始事った。さらに 3 日後（第13病日）の 朝，縫合部からふたたびにじみ出るよらな出血が 始まり，王迫止血を試みたが止血できなかつた。 出血部位検索のため術部を開き細静脈からの出血 は縫合できたが，毛細血管からの出血は凝固する ことなくつづき，スポンゼル，酸化セルロースを 用いてもな拈止らず，止血㨈（トロスチン，レプ

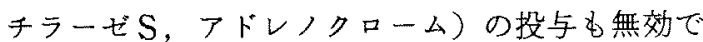
あつた。ただ創部にトロンビンを滴下すると，わ ずかながら凝血するのが垫められた。第14病日の 検查では血沈は著しく元進しており，血小板数は 正常で, ADP・ウシフィブリノーゲン・リスト七 チン・コラーゲンの添加による血小板凝集能は正 常であつた，血中フィブリノーダンは高值で, $\mathrm{PT} ・ \mathrm{APTT} ・ \mathrm{KPTT}$ は著明に延長していた（表
2).これらの所見から播種性血管内症候群(DIC) は否定され，凝固因子活性の異常による血液凝固 障害と推定した。 その原因としてunder dialysisが 考えられたので, 1 回のPD量をらやし連日実施し た，4 日後の再検査でも $\mathrm{PT} \cdot \mathrm{APTT} ・ \mathrm{KPTT}$ はい ぜん延長しており，さらにトロンボテスト，へパ プラスチン時間の著明な延長と凝固系 II， VIl，X 因子活性の著しい低下，IX因子活性の軽度低下が みられた（表 2 ）。一方，この間GOT・GPTは正 常で, ICG停滞率は5.1\%, 血中アンモニアは測定 感度以下，肝シンチグラムは正常像であり，肝機 能異常は否定された。 またphytonadione投与後， 凝固学的異常はすみやかに改善した(表 2 ). 以上 の所見から，本例の出血菜因はビタミン $\mathrm{K}$ 久乏に よると診断した。

検查所見に和いて，8月10日の第II因子の活性 は3\%と著明な低值であつたものの，抗原量は6 $\mathrm{mg} / \mathrm{dl}$ (正常値9 12mg/dl) で正常の䄪60\%すあ り，活性值と抗原量にはdiscrepancyがみられた。

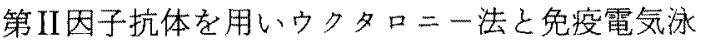
動法による免疫学的方法にて検索したところ，前 
表 2. phytonadione投与前後の検查結果の推移

\begin{tabular}{|c|c|c|c|c|c|c|c|c|}
\hline 経 & 過 & 入院時 & Aug $/ 7$ & 10 & 13 & 18 & 31 & Nov /17 \\
\hline \multicolumn{2}{|c|}{ phytonadione } & \multicolumn{7}{|c|}{$\checkmark$} \\
\hline \multicolumn{2}{|c|}{$\begin{array}{c}\text { 血 沈 }(1 \mathrm{~h}) \\
\text { 血小板数 }\left(\times 10^{4}\right)\end{array}$} & $\begin{array}{l}120 \\
22.3\end{array}$ & $\begin{array}{l}78 \\
29.3\end{array}$ & 33.3 & $\begin{array}{l}89 \\
40.6\end{array}$ & 24.9 & & \\
\hline $\mathrm{P}$ & (秒) & 16.2 & $>45$ & $>45$ & 16.2 & 14.2 & 14.7 & 13.0 \\
\hline A P & (秒) & 25.8 & 64.9 & 90.6 & 20.9 & 21.9 & 24.6 & 25.2 \\
\hline K P & (秒) & 80.0 & $>200$ & $>200$ & 47.6 & 44.6 & 55.2 & 40.1 \\
\hline \multicolumn{2}{|c|}{$\begin{array}{l}\text { トロンボテスト }(\%) \\
\text { ノルモテスト }(\%)\end{array}$} & & & $\begin{array}{l}<5 \\
<10\end{array}$ & & $\begin{array}{r}68.5 \\
107.3\end{array}$ & $\begin{aligned}> & 100 \\
& 90.0\end{aligned}$ & $\begin{array}{l}100 \\
122.5\end{array}$ \\
\hline \multicolumn{2}{|c|}{$\begin{array}{r}\text { FD P }(\mu \mathrm{g} / \mathrm{ml}) \\
\text { HMWFC }(\mu \mathrm{g} / \mathrm{ml})\end{array}$} & & 0.14 & 32 & & 16 & & \\
\hline \multicolumn{2}{|c|}{ フィブリノーヂン $(\mathrm{mg} / \mathrm{dl})$} & 600 & 530 & 476 & & & 445 & 470 \\
\hline $\begin{array}{c}\text { 凝 } \\
\text { 固 } \\
\text { 因 } \\
\text { 子 } \\
\text { 活 } \\
\text { 性 } \\
(\%)\end{array}$ & $\begin{array}{c}\text { II } \\
\text { V } \\
\text { VII } \\
\text { VIII } \\
\text { IX } \\
\text { X } \\
\text { XI } \\
\text { XII } \\
\text { XIII }\end{array}$ & & & $\begin{array}{r}3 \\
110 \\
3 \\
260 \\
64 \\
<2 \\
84 \\
200 \\
100 \\
\end{array}$ & & $\begin{array}{l}100 \\
120 \\
170 \\
260 \\
300 \\
125 \\
100 \\
250 \\
120 \\
\end{array}$ & $\begin{array}{r}82 \\
115 \\
120 \\
180 \\
165 \\
68 \\
110 \\
200 \\
100\end{array}$ & $\begin{array}{r}115 \\
110 \\
155 \\
340 \\
210 \\
96 \\
125 \\
320 \\
140 \\
\end{array}$ \\
\hline \multicolumn{2}{|c|}{ II - A 抗原量 $(\mathrm{mg} / \mathrm{dl})$} & & & 6.0 & & 11.4 & 9.6 & 12.6 \\
\hline
\end{tabular}

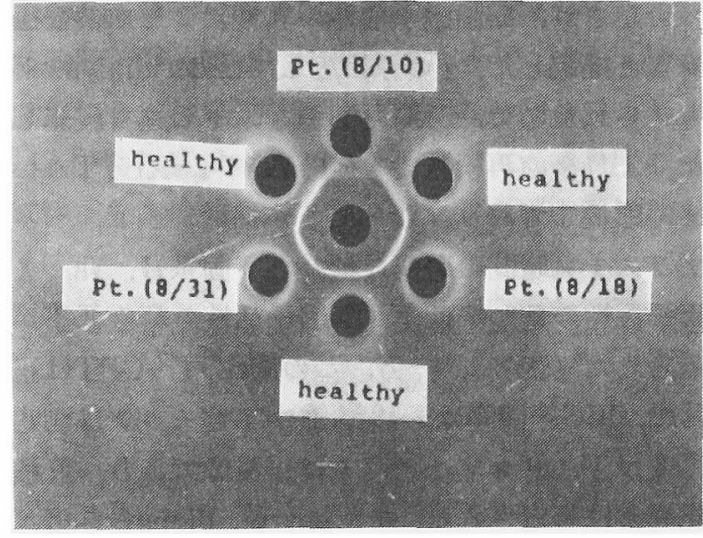

図 2．抗第II因子抗体との沈降線，治療前のもの(8 月10日)では正常の沈降線の汪かspur形成むみられる。

者では治療前（8月10日）の沈降線は移動度の異 なる 2 本がみられ，治療後 (8月18日，31日の分） は健康人之まつたく同一であつた(図 2 )。 また後 者では，治療前の“第II因子”の移動度は治療後の もの怙よび健康人のものと異なり速く泳動されて いた(図３）。これはビタミン $\mathrm{K}$ 欠乏に伴つて物理

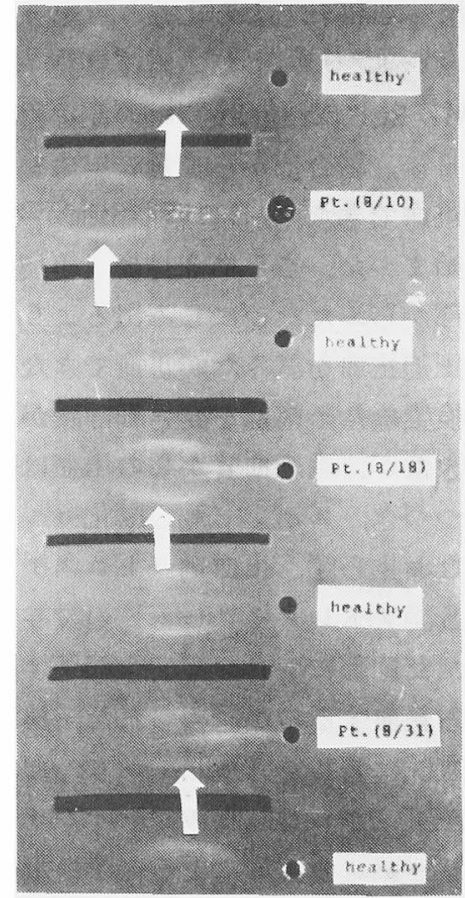

図 3.電気泳動による移動をみると, 治療前のもの( 8 月10日）ではほかのものに比べ速く移動している. 


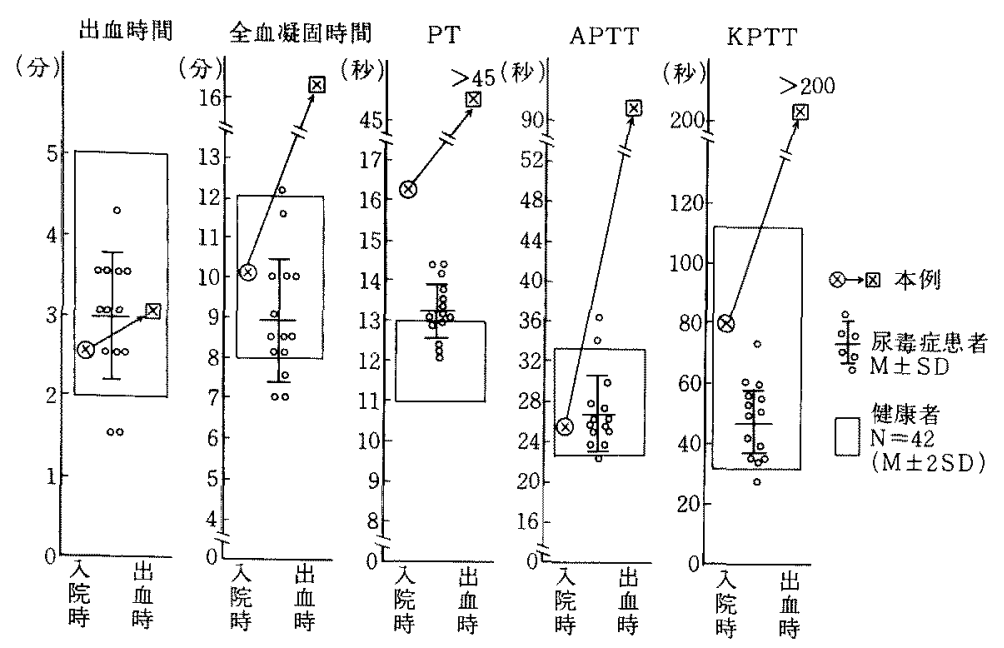

図 4 尿症患者との比較でみた血液凝固学的検査の結果

化学的に性状の異なるプロトロンビン分子が血中 に増加したものと推定した。

\section{考案}

腎障害が進行すると代謝産物が蓄積し，血小板 機能や凝固因子活性に影響して血液の凝固異常が 生ずる。そのため鼻出血や皮䖉の出血斑をみるこ とがある。しかし，大量出血につながるような出 血傾向に陥ることはない，李た尿毒症状態になる と消化器症状のために食事摄取量が減少したり， 食事制限に伴う栄養素のアンバランスが扣こる が，ビタミンK不足による出血素因になることは ない。

われわれの症例は高令で, 長期間の加療ののち 腎機能が低下し尿毒症に陌つた例である。入院前 の数日間，食事量は減少していた。入院時口唇か らの俥微な出血をみたが，それ以外出血症状がな く，検查ではPTが延長していたものの出血時間・ 全血凝固時間・APTT・KPTTは采つたく正常域 内にあつた。腹膜透析法により症状が改善したと ころで内シャントをつくり，抗生物質を投与した。

本例にみられた出血素因の原因として第一に挙 げられるのは，尿毒症症状としての出血傾问であ る.PDは順調に行なわ机てBUN, クレアチニンは 低下し，臨床症状多著しく好転していた（図 1)。 しかしunder dialysisの可能性は否定できず透析
量をふやしたが，通常尿毒症状態にあつても本例 のごとき凝固因子活性の著明な低下をみることは ない，第 2 に挙げられるのは急性肝不全である。 本例では凝固因子活性の異常とともに血清コリ ン・エステラーゼ活性む低值であつた。しかしト ランスアミナーゼ活性やビリルビン, アンモニア はすべて正常範囲内にあり，亲たフィブリノーゲ ンはむしろ高值でICG停滞率や肝ンンチグラムに あ異常はみられなかつた，第3に举洁られるのは DICである．FDPは軽度上昇していたものの血小 板数は正常で，血沈は元進して和り，血中フィブ リノーゲンはむしろやや高值であつたことから DICは否定できる、第 4 に挙げられるのはビタ ンK欠乏症である。 protein induced by vitamin $\mathrm{K}$ abscence (PIVKA) と総称されているプロトロ ンビン，第VII，IX，X因子の前駆体分子は，肝に 扔いてつくられている。これらが分子構造上の変 化を持こす過程で，この脂溶性ビタミンが重要で あることは以前より知られていたことであるが， 最近とくにブロトロンビンの代謝過程の研究にお いて詳細な作用機序が解明された2). 本例では血 中フィブリノーゲン抗原量が高值で第 V, VIII因子 活性は正常ないし高値でありながら、ビタミン $\mathrm{K}$ 依存性因子だけは著しい活性低下を示していた。 そしてこれらの異常はphytonadione投与 3 日後 
には顕著な改善をみ，出血症状も消退した。一般 的に尿毒症期にはPTはやや延長しているすのの APTT,KPTTは正常で（図 4)，第VII，VIII，IX因 子活性は高値であるといわれており 合は著しく異なつていた，以上のことから，本患 者にみられた血液凝固障害はビタミンKの欠乏に 起因すると穆断した。

乳児にみられるビタミンK久久性出血は1966年 の報告以来よく知られており，本邦でもすでに 38〜100例の報告例がある4). ビタミン $\mathrm{K}$ の主た る供給源は乳児と成人とではかなり異なつてい る、乳児では腸内細菌である大腸菌から大量のビ タミン $\mathrm{K}_{2}$ が供給されるに比し，成人で惊食物から

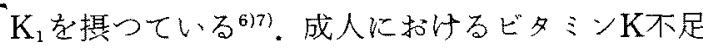
は希で，長期間の食事量不足やアンバランスな食 事摄取，高度の肝・胆道疾患，慢性下病・脂肪性 下痢，手術後などに発症することが知られている。 また広域性抗生物質の投与に関連して括こること もあり，扔そらく腸内細菌叢の变化，ビタミン $\mathrm{K}$ 合成障害, 肝障害の惹起など火伴うものと考壳ら れる、ビタミンK欠乏に伴つてプロトロンビンだ けが低值を示すような低プロトロンビン血症だけ では，出血症状を呈するまでには至らないといわ れ，低栄景，下沜，抗生物質の投与の悪条件の5 ら二つ以上が重複し，第II囚子以外のPIVKA系因 子の異常る加わつたとき，出血傾向に陷つてしま らといわれている.

われわれの患者がビタミンKの欠乏症を併発し た理由として，高令であること，高度の腎障害が あること，そしてそのため栄養状態が悪化してい たことが重要であると考えられる。このため体内 に貯蔵されていたビタミンKむ枯渴し，入院時に すでにPTだけは延長していたものと思われる。通 常ビタミンKの欠之症に陥るのは，3〜4週間の 食事摂取不能がつついていた時とされている9! しかし，食事摄取にのみ障害のある患者に，ビタ ミンK剤の投与を行ならことなく数力月間高力口 リ一輸液だけをつつけけていも, 出血症状を子る ことは少ない，一方, Pineo ${ }^{10)}$, Rymerら ${ }^{11)}$ の患 者や本例では，1週間といら比較的短期間で発症
していることは注意せ极ばならない、したがつて， 低栄盖状態や抗生物質の投与をらけている患者に おいては，きわめて短時日のらちにビタミンK不 足に陷つてし亦うと考兵られる。

ビタミンKの欠乏状態ではPTやPTTが著しく 延長し，トロンボテストやへパプラスチン・テス 卜も極端な低值となる。とくにPTが25秒以上にな る例では，大出血を扣こす危険性がある10).ビタミ ンK不足に上る出血傾向予知するには, PTの測

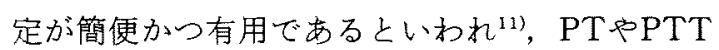
の測定が今日では自動化されて広く普及している ことから実用性が高い.本例ではPTが45秒以上で あり, シャント手術部からの出血・口唇からの出 血・タール便があつたが, phytonadioneが著効し た、したがつて悪条件の重なる患者に打いてはと きどきPT, PTTを調べ，ビタミンK風投与を念頭 に颃いて和けばビタミンK久乏性出血症を予防で きる。

ビタミン $\mathrm{K}$ 久泟を併発した患者の基礎疾患を 文献的に調べてみる之，急性乱よび慢性腎不全， 糸球体腎炎などの腎障害(例1012)方散見されること から，高度の緊疾患患者ではとくに注意を要する。 腎障害が進行すると薬物の半減期が延長し，副作 用の頻度も高くなる。胆道系への排泄が多い抗生 物質では腸肝循環によつて副作用が堌強される可 能性があり，とくに注意されるべきである ${ }^{13)}$.今回 使用したCMZは，従来より使用されているCEZよ り胆汁への移行性が高いといわれて拈り ${ }^{14}$ ，腎不 全患者に招いては腸内細菌への影響为大きいと考 えられる。

ビタミンK欠乏時やwarfarin投与時にはビタ ミンK依存性carboxylaseが阻害されるため,プ ロトロンビンの前駆体分子 (descarboxyproth-

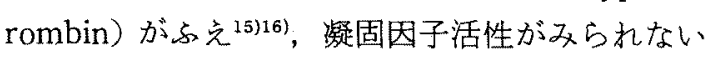

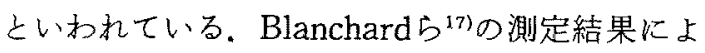
ると，プロトロンビン前駆体分子は健康人の血中 にはなつたく検出できなかつたが, 肝硬変患者, ビタミンK久乏患者, warfarin投与患者では増加 していたと述べている。おれわ机の例に批てては 第II因子活性が $3 \%$ と著明な低值であつた。これ 
は第II因子の半滅期が 4 時間であることから、す でに正常プロトロンビン分子は著しく隇少してい たものと考えられる、ところが免疫学的方法で第 II因子の抗原量を測定すると軽度の低下にとどす つており(表 2 ), 活性値と抗原量に解離がみられ た. phytonadione投与の前後に颃いて第II因子の 免疫学的性状を調べたところ，治療前のものでは 治療後や健康人のものとは異なる速い移動度をむ つ沈降線がみられた(図 3)。ビタミンK久乏によ り $\gamma$-carboxylase $か ゙$ 阻害されて descarboxyprothrombinから正常プロトロンビン分子への転 換が障害され，第II因子の活性が極度に低下した もの之推定される。

今日のところビタミン $\mathrm{K} の 1$ 日必要量はまだ明 らかにされておらず，末た欠乏時の最低投与量も 決李つていない(18)，患者は現在，毎月 1 回40mgの phytonadioneの投与を受けながら通院透析をつ ぶけている。この間, 連日つづく発熱に対して CMZの投与を行なつたが，凝固検査の異常はみら れなかつた。したがつて本例にみられたビタミン K欠乏症は，ビタミン $\mathrm{K}$ 合成においてCMZが直接 的な阻害効果を示したものではないと考克られ る。

\section{結 語}

出血傾向を示すいくつかの矩患のうち, 成人に おいてはビタミンK久性出血症をみることは亦 れとされている。しかし，高令者でとくに腎障害 があつて摂食量も減少している状態では，ビタミ ンKが欠乏しやすいと思われる。ささらに抗生物質 の投与や下痢がつづく場合には腸内細菌からのビ タミンKの補給が断れるため，容易に欠乏してし まう。ビタミンK欠之症が予期される患者では PT, PTTのチェックが簡便で有用である。

謝辞 最後に, 当院六病棟内科の諸先生の御協力・御教 示に深勆します。

\section{文献}

1) Rabiner SF: Bleeding abnormalities. Massry SG and Sellers AL, ed. Clinical Aspects of Uremia and Dialysis, Charles C Thomas, Illinois, 1976, p179.

2) Esmon $\mathrm{CT}$, et al: A new carboxylation reac- tion. The vitamin $\mathrm{K}$-dependent incorporation of $\mathrm{H}^{14} \mathrm{CO}_{3}$ into prothrombin. J Biol Chem 250: 4744,1975

3）武内重五郎，中川成之輔：慢性腎不全，血液凝圄 異常. 武内重五郎編。臨床腎臓病学せミナー [3] 堅不全。南江堂, 東京, 1979, pl16.

4）中山健太郎，他：乳児ビタミン K火性出血症。日 本医事新報，No. 2996，p22，1981.

5）若林 修，他：ビタミンK欠症にもとつく出血 死の 1 剖検例。最新医学 $35: 839,1980$.

6) Dam $H$ and $S \phi$ ndergaard $E$ : Fat-soluble vitamins-Vitamin K. Beaton and McHenry, ed. Nutrition, Vol. II, Academic Press, 1964, p60.

7) International microflora, injury and vitamin $\mathrm{K}$ deficiency. Nutrition Review 38: 341, 1980.

8）白井鎮夫，他：ビタミンK欠之症に基づく乳児頭 蓋内出血一自発性脳内括上び硬膜下血腫の 1 治験 例一。脳之神経 $28: 1359 ， 1976$.

9) Ham JM : Hypoprothrombinemia in pa-tients undergoing prolonged intensive care. Med J Aust $2: 716,1971$.

10) Pineo GF, et al: Unexpected vitamin $K$ deficiency in hospitalized patients. Canad Med Assoc J 109: 880, 1973.

11) Rymer W and Freenlaw CW : Hypoprothrombinemia associated with cefamandole. Drug Intell Clin Pharm 14:780, 1980.

12) Lerner PI and Lubin A: Coagulopathy with cefazolin in uremia. New Engl J Med 290: 1324, 1974.

13) Hooper CA, Haney $\mathrm{BB}$ and Stone $\mathrm{HH}$ : Gastrointestinal bleeding due to vitamin $\mathrm{K}$ deficiency in patients on parenteral cefamandole. Lancet I : 39, 1980.

14）二之宮晃光：CS-1170kか九する基礎的，䠦床的 研究一特心胆斗中排泄を中心に一。外科診療 $20: 1639,1978$.

15) Ganrot PO and Hilén J-E: Plasma prothrombin during treatment with dicumarol. II. Demonstration of an abnormal prothrombin fraction. Scand J Clin Lab Invest 22: 23, 1968.

16）所藤雄，他：抗生物質上経口摄取不足により vitamin $\mathrm{K}$ dependent factor deficiency し, 出血傾向之異常第II因子の出現を灭大 2 症例. 日血会誌 $40: 178 ， 1977$.

17) Blanchard RA, et al: Acquired vitamin Kdependent carboxylation deficiency in liver disease. New Engl J Med 305 : 242, 1981.

18) Mandel HG and Cohn VH: Fat-soluble vitamins. Gilman AG, Goodman LS and Gilman A, ed. The Pharmacological Basis of Therapeutics, MacMillan Inc, New York, 1980. 